\title{
A Semantic Analysis of the Notion of Consultative Democracy: Xieshang Minzhu （协商民主） in the Chinese Official Political
}

\section{Discourses}

\author{
Rongxin $\mathrm{Li}^{1}$, Xiaofang Zhou ${ }^{2}$ \\ ${ }^{1}$ Research Center of Sociology and Politics, UMR 7017 CNRS, Paris 8 \\ University \\ ${ }^{2}$ Formal Structures of Language Studies, UMR 7023 CNRS, Paris 8 University
}

\begin{abstract}
Chinese politics are characterized by the complex issues of a large population and centralized political powers, which offers a distinct political model from the Western models. However, the last two decades have witnessed a sharp collision between Chinese and Western political thinking. In response, domestic authors have increasingly focused on the indigenization (bentuhua 本土化) of Chinese political theories and, therefore, defend the concept of politics with Chinese characteristics. In this article, the authors focus on the discourse of "deliberative democracy" within the Chinese language, namely, Xieshang minzhu 协商 民主. In the current literature, almost no scholarly discussions have explored the semantics of the notion of Xieshang minzhu within Chinese politics. This article engages with this issue, both as a subject and a methodology, to better understand the political language that has been used in the official discourses in China ${ }^{1}$ by 1) establishing a textual corpus by collecting relevant data into the Chinese and English groups through keywords; 2) conducting a statistical analysis based on the Word Cloud and Diagram analyses; and 3) using Word2Vec to calculate the relationship among other sub-keywords. The purpose of this contribution is to differentiate Xieshang minzhu as adopted by Chinese official discourses embedded in the logic of political reforms from the Western discourses. The semantic analysis presented here also serves as a methodology
\end{abstract}

\footnotetext{
* Rongxin Li (corresponding author), Research Center of Sociology and Politics, UMR 7017 CNRS, Paris 8 University; johnsonli2.aiesec@gmail.com; Xiaofang Zhou, Formal Structures of Language Studies, UMR 7023 CNRS, Paris 8 University; zhouxiaofang0125@outlook.com. Note that the deliberative democracy in English (commonly seen in Anglo Saxon literature) and the Xieshang minzhu in Chinese have complex, overlapped but inequivalent corresponding relations. Many authors equate the two, or, with the introduction of so-called new political norms (e.g. authoritarian deliberation/consultation) to defend themselves, and thus to explain the part of the realities of Chinese Xieshang minzhu, and even Chinese political science, which tends to be unpersuasive and incomprehensive. In this article, the authors defend the idea of the Xieshang minzhu in the Chinese context using a semantic model rather than the ontology analysis to elucidate the embedment of the Xieshang or Xieshang minzhu in China's politics and to explode its strong vitality.

1 Official propaganda mainly includes five of China's most authoritative official media (newspapers): People's Daily (Renmin ribao 人民 日报), Guangming Daily (Guangming ribao 光明 日报), Xinhua Daily(Xinhua ribao 新华 日报), China Comment (Banyutan 半月谈), Qiushi (Qiushi 求是, formerly known as Red Flag (Hongqi 红旗)), Xi Jinping's series of important speech databases and official documents on the subject of Xieshang or Xieshang minzhu in the Party-Building Database.
} 
that systematically develops a conceptual model of xieshang, which further clarifies the misconceptions and errors in the existing literature. The authors also provide an outline of the polysemic notion of deliberative democracy, which not only exists within an authoritarian regime but is also present in other forms and other languages (such as Chinese). This serves to further maintain the legitimacy of the "socialist democracy with Chinese characteristics."

\section{Keywords}

semantic analysis; Xieshang minzhu; Chinese language; indigenization; authoritarian rule

\section{A Conceptual Model for Xieshang minzhu in the Chinese Context}

The contemporary political study mainly involves formal ontological engagement, and it sometimes lacks semantic clarity. Ontologies, to some extent, are static, but with a limited role in reasoning about domains in which change matters, ${ }^{2}$ especially facing a divided society with different political status quo, including language, culture, history, and so on, which usually presents multilingual polities. In particular, linguistic barriers are thought to pose obstacles to politics (Doerr Nicole, 2012), and they can also cause problems in democratic inclusion in linguistically pluralist polities. ${ }^{3}$ Thus, for a political term, it first comes to the semantic and linguistic lens and then travels to the conceptual (Mulieri, 2016), thus, for the "conceptual analysis," it should function as the speech-acts that belong to ordinary life as a way of "exercise in language philosophy." Its interpretations depend on the specific historical, social, and political contexts rooted in different linguistic experiences (Koselleck,1979), which are simultaneously subject to continuous change. This means that the first effort that we should pursue in analyzing the concepts is to look at how a given word has been associated with different meanings based on a certain language. Thus, to the case of deliberation, it is not a concept fixed by its identical object nor is it the name of a thing, but it is rather a semantic and collocation expression ${ }^{5}$ that we can handle in different ways, according to the sense that it can take within a determined context.

2 Atkinson Katie M. et al (2011). Semantic Models for Policy Deliberation. Proceedings of the 13th International Conference on Artificial Intelligence and Law. ACM.

3 Fiket, I., Olsen, E.D.H. and Trenz, H.-J. (2011). Deliberation under Conditions of Language Pluralism. Insight from the Europol's Deliberative Polling Experiment. Arena Working Paper. Vol(9).

4 Pitkin, Hanna F. (1967). The Concept of Representation. Berkeley: University of California Press.

5 Hofmann Hasso (1964). Legitimität gegen Legalität: der Weg der politischen Philosophie Carl Schmitts. Neuwied: Luchterhand. 
The variety of the semantic differences for the notion of deliberation is perhaps easier to articulate in those languages in which the different meanings correspond to different words. The semantic richness can be somehow regarded as a conceptual stretching of deliberation (Jürg Steiner, 2008; David Austen-smith and Timothy J. Feddersen, 2008). Thus, the deliberation per se should go beyond the standard understanding in political science and look for new theoretical models to deal with the emerging rise of transnational and polysemic of politics. This gap, which is especially highlighted among nations, is still fraught with linguistic and conceptual misunderstandings. For example, the mainstream Chinese discourse tends to describe China as an undemocratic state, thus leaving no room for deliberation, even though this view does not exist in China itself. China's authoritative definition of Xieshang minzhu is as follows:

Xieshang minzhu in China is an important form of democracy under the leadership of Chinese Commubist Party (CCP) in which various sectors of the people conduct extensive consultation before and during the implementation of policy decisions on major issues concerning reform, development and stability, as well as practical issues concerning the vital interests of the people with the effort of forming the consensus.

In China, the concept of Xieshang minzhu is derived from the speech of "three norms of democracy" that was made by Habermas in China in 2001. In line with the political consultation system in China, this overlapped and coupled at the time and immediately caused great interest from domestic scholars (Sun Dehai and Fang Shinan, 2015), with abundant academia achievements on the discourse. Thus, the mainstream in China holds the view that "China now, gradually formed China's indigenous consultative democracy discourse system,' and therefore, finally entered the ideological discourse system of the CCP and state." Nevertheless, our main contribution in this article is not to review the mass academia literature because they are sometimes discrepant with current policies, but instead, we aim to make an official discourse analysis. The second section of this article introduces the overall methodology and it will establish the corpus. The last section analyzes the official discourse of Xieshang minzhu in the Chinese context, and it is probably the best-fit form during the democratic transition (if any) and political reform in China.

6 Opinions of the CCP Central Committee on Strengthening the Construction of Socialist Consultative Democracy (2015). Available at http://www.lyzzxs.gov.cn/zxzs.php?newsid=11756.

7 Ma Ben (2014). "Xieshangminzhu yu xuanjuminzhu: yuanyuan, guanxi yu weilaifazhan. (Consultative Democracy and Electoral Democracy: Origin, Relationship and Future Development)". Wenzheshi. Literature, history and philosophy. Vol(03): pp.21-26. 
Rongxin Li, Xiaofang Zhou A Semantic Analysis of the Notion of Consultative Democracy Key Differences Between Anglo-Saxon Literature and Chinese Indigenized Scholarship of Deliberative Democracy

To date, the Anglo-Saxon literature of deliberation largely excludes the experiences of (quasi)-Xieshang in China, that is, another different setting that attempts to reconcile deliberation within an authoritarian regime. In this article, although the authors try to adopt a fresh non-Western perspective for further analysis, we still try to highlight the authentic context of China's Xieshang minzhu by indicating the intrinsic differences between China and the West on deliberation and fill this void calling for a renewed attention to the indigenization of the local political studies and also for the better understanding the Chinese governance in non-Western societies.

Traditional politics assumes a strong affiliation between deliberation and democracy, but the "authoritarian deliberation" coined by He Baogang (2012) strongly indicates the coexistence of authoritarianism and deliberation in a nondemocratic state (with 20,932/13.1\% of "deliberation" and 1,478/5.7\% of "authoritarian": in English, it is $0.89 \%$ as the high-frequency words, see Appendix 1). Nevertheless, the criticisms were also crucial; for example, Leib (2005) stated that "we were ready to call almost any participatory institution seemed too generous, given that this participation was occurring within a country without the most basic of democratic indicia: competitive elections on the national level and basic liberal rights." ${ }^{\prime}$ Chart 1 and Appendix 1 indicate a quite large promotion with "party (with the correlated words like 'monopoly' (0.79), 'dominate' (0.76), 'control' (0.74), 'leadership' (0.71))" and 'state' (0.92), 'regime' (0.98) share $24.2 \%$ totally while democracy only share $13.10 \%$. In addition, the debate between Jürg Steiner $(2008)^{9}$ and David Austen-Smith et al. (2008) about the concept stretching for deliberation, which also showed the concern about the misunderstanding and misinterpretation for deliberative democracy, both theoretically and practically, in China. 
Chart 1 WordCloud in Chinese and English

\begin{tabular}{|l|l|l|l|l|}
\hline \multicolumn{5}{|l|}{ WordCloud in Chinese (top 20 key words) } \\
\hline 民主 (Minzhu, democracy) & 社会主义 (Shehuizhuyi, Socialist) & 人民 (Renmin, People) & 政治 (Zhengzhi, Politics) & 改革 (Gaige, Reform) \\
\hline 协商 (Xieshang) & 制度 (Zhidu, Institutionalization) & 国家 (Guojia, State) & 特色 (Te'se, Characteristic) & 习近平 (Xi Jinping) \\
\hline 中国共产党 (Gongchandang, CCP) & 发展 (Fazhan, Development) & 建设 (Jianshe, Constrction) & 基层 (Jiceng, Local) & 领导 (Lingdao, Leadship) \\
\hline 群众 (Qunzhong, Public) & 体制 (Tizhi, System) & 问题 (Wenti, Problem) & 治理 (Zhili, Governance) & 团结 (Tuanjie, Solidarity) \\
\hline WordCloud in English (top 20 key words) & \multicolumn{5}{|l}{} \\
\hline Democracy & Deliberation & Political & Participant & Power \\
\hline Public & Policy & Government & Discussion & Chinese \\
\hline System & State & Party & Politic & Regime \\
\hline Citizen & Local & Reform & Consultation & Official \\
\hline
\end{tabular}

Note: Based the WordCloud, the differences that in the main keywords of the built Chinese and English corpus can be intuitively reflected, but the primary and secondary relationship of specific keywords cannot be examined for the moment. So, we set up a diagram in the top 20 words to reflect the primary and secondary relationship of keywords.

An authoritarian deliberation is both logically possible and empirically real. ${ }^{10}$ In the new formulation proposed by $\mathrm{He}$, he continues to defend the ideas with various arguments in the last few years. The objectively raison d'etre of Xieshang or Xieshang minzhu in China that distinguishes with the Western discourse is largely due to its functional orientation, namely Xieshang minzhu in China, which is the instrumental existence, that is "problem-oriented" (Wenti 5741 in Chinese). This is in line with the typical pragmatism in Chinese politics, that "for reducing social conflicts and the level of opposition, and facilitating compliance with and implementation of state policy, also, it can be an effective decision-making process, being an effective conflict-resolution device, and a means to overcome polarization" (He Baogang, 2016). First, authoritarian deliberation may merely exist in Chinese local governance, which is traceable especially in the coastal areas in China in recent years. The so-called deliberative experiments (e.g. Zhejiang Wenling, Shanghai, etc.) are far from generalizing the panorama of Xieshang minzhu in China. Including the inter-party consultations advocated by CCP, the Chinese People's Political Consultative Conference (CPPCC) consultations centrally are merely formalistic. In addition, He thinks that the theoretical and practical tensions between deliberation and authoritarianism can hopefully be transformed into a driving force toward democracy (He, 2012, 2016). 
The debate on deliberative democracy in Western academia views that liberal (representative) democracy is the foundation of deliberative democracy with electoral and competitive politics. However, it is acknowledged that competitive elections might inhibit genuine deliberation. Nevertheless, genuine democratic deliberation must be structured accordingly to elections, which are lacking in China. However, the local experiments that have even adopted high-technique methods still fail to be sufficiently deliberative and to be sufficiently representative ( $\mathrm{He}, 2016)$. Against this background, Western theorists firmly stress the important role of a public sphere and civil society in developing deliberative democracy. Habermas (1994) and Dryzek (1990) stated that "[I]t can flourish only by creating, operating within, and confronting the state from an autonomous public sphere," but these key factors may be problematic in the Chinese political context under a powerful state and monopoly party (as we mentioned before, the state-sponsored/officialbackground deliberative activities are quite narrow and limited within the authoritarian control), even with the hint that lack of active involvement of civil society and may, therefore, pensively lead to the authoritarian deliberation in China, but the hope is slim and unclear.

To date, based on the keywords distribution and proportion in Chinese and English in Chart 2 indicate, the key differences between the two lie essentially in the different polity that it relies on, namely liberal (representative) democracy and socialist democracy, that further shaped the different civil society (that with the key democratic elements within, such as freedom of speech, association, NGOs, etc.), as well as the manifold comprehension of the function toward deliberation. That is, Xieshang or Xieshang minzhu in China is largely affiliated to the conflict-resolution (see Appendix 1 with the highfrequency keywords like the noun "problem" $>5,000$, verb like "governance," "solve," "deal with">4,000) mechanisms with the nature of instrumentality or somehow transition for further democracy. But in liberal (representative) democracy, being a form of democracy, it is the authentic "talk" among the public, at least ideally. These differences appeared in the charts with highfrequency vocabulary, which summed up as socialist deliberative democracy with Chinese characteristics $(>29,200)$ and can also be found with vast differences through a comparison between Western and China based on a rustic view of democracy. Thus, this part is not for the sake of distinguishing the relative merits in either party but, also in the third part, to demonstrate how Xieshang minzhu is embedded in Chinese politics in its way. 
Journal of Nationalism, Memory \& Language Politics 14(1)

Chart 2 Keywords Distribution in Corpus

\begin{tabular}{|c|c|c|c|}
\hline \multicolumn{2}{|c|}{ Distribution in Chinese Corpus } & \multicolumn{2}{c|}{ Distribution in English Corpus } \\
\hline 民主 (Minzhu) & $17.26 \%$ & Democracy & $13.10 \%$ \\
\hline 协商 (Xieshang) & $16.99 \%$ & Deliberation & $13.10 \%$ \\
\hline 制度/体系 (Zhidu/Ti'xi) & $12.01 \%$ & System & $4.73 \%$ \\
\hline 群众/人民 (Qunzhong/Renmin) & $11.63 \%$ & Society & $4.84 \%$ \\
\hline 政治 (Zhengzhi) & $6.94 \%$ & Political & $17.46 \%$ \\
\hline 国家 (Guojia) & $7.25 \%$ & state/regime & $12.07 \%$ \\
\hline 治理 (Zhili) & $2.96 \%$ & Governance & $5.60 \%$ \\
\hline 基层 (Jiceng) & $3.08 \%$ & Local & $7.35 \%$ \\
\hline 社会主义特色 (Shehuizhuyi T'se) & $13.84 \%$ & Party & $11.25 \%$ \\
\hline 改革 (Gaige) & $4.57 \%$ & Participation & $4.80 \%$ \\
\hline 领导(Lingdao) & $3.45 \%$ & Authoritarian & $5.70 \%$ \\
\hline
\end{tabular}

\section{Methodologies and Corpus Establishment}

Foundation of the Acquire Documents

The textual analysis is based on a database that was established on the official propaganda after the 18th NPC (2013), which, for the first time, officially adopted Xieshang minzhu. Our data sources are originally derived from the official databases with the title=“Xieshang minzhu (协商 民主)" or keywords= "Xieshang minzhu" with a total of 2,018 items ${ }^{11}$ through advanced (fuzzy) search. ${ }^{12}$ Although the authors did not sort the data before 2013, clearly, before the 18th National Congress, the official interpretation of Xieshang minzhu was not systematically engaged; notably, it was mainly conducted by scholars within the academia discussion. In contrast, after the 18th National Congress, academic discussion and official propaganda increased positively. Three main axes will be involved from an official perspective, as follows: I. official propaganda (newspapers); II. leaders' speeches, especially Xi Jinping's discourses on Xieshang minzhu; and III. official documents related. 
I. The five most authoritative official media (newspapers) in China ${ }^{13}$ are the People's Daily (Renmin ribao 人民日报) for 458 reports, Guangming Daily (Guangming ribao 光明日报) for 560 reports, Xinhua Daily(Xinhua ribao 新华日报 447 reports), China Comment (Bnayutan 半月谈 320 reports), Qiushi (Qiushi 求是 37 reports, formerly known as Red Flag (Hongqi 红旗 86 reports)).

II. The top leaders' series of important speech databases with 95 items. ${ }^{14}$

III. Official documents on the subject of Xieshang or Xieshang minzhu in the Party-Building Database with 15 items. ${ }^{15}$

Although the antitheses between China and the West are not the focus of this article, we still carried out a rhetorical and semantic analysis of the Chinese indigenous studies with the English literature by establishing a database on deliberative democracy (the elucidation in the first part is a mirror case). Given that the Western literature of Xieshang minzhu does not appear in Pinyin, the keywords are "deliberative democracy," or "deliberation," or "consultation." The main source of the database comes from the Bibcnrs ${ }^{16}$ and Google Scholar, with 124 articles (including overlap) related to the topic and processed in the same way.

13 To date, given that the Xieshang minzhu is a political term, thus, the authoritative official media chosen are target to the political newspaper and media by CCP. These China's largest-circulation newspaper and also known as the propaganda of the CCP (Dangmei 党媒), the published articles and reports that expressed the CCP's official views. To note, the overlapping part that among the various newspapers and social media have, for example, the People's Daily and the Guangming Daily may jointly report the same content at the same time. Although the selection of the newspapers that all belong to the central media, they also reprinted in the local media reports about Xieshang minzhu. People's Daily also quoted the related contents that from the local media such as Guangxi Daily (Guangxi ribao 广西日报), Tibet Daily (Xizang ribao 西藏日报), Shandong Daily (Shangdong ribao 山东日报). Therefore, the target data selected in this study cover almost all reports and analyses of Xieshang minzhu by central and local media from 2013 to 2019.

14 This is mainly Xi Jinping's important discourses on Xieshang minzhu since the 18th National Congress, within which also includes Zhao Leji-member of Standing Committee of Political Bureau of CCP Central Committee in the 2013 survey in Shanghai: vigorously promote the construction of grassroots service-oriented party organizations and strengthen the communication and consultation between grassroots party members and the public, the emphasis in 2013 by Liu Yunshan-member of Standing Committee of Political Bureau of CCP Central Committee that strengthened and improved the party's leadership over comprehensive and deepening reforms, and deepen inter-party consultations. Available at http://djsjk.people.cn/search/index/338979 and http://jhsjk.people.cn.

15 The official documents include an official document on Xieshang minzhu released by the CCP central committee, as well as relevant meetings, theoretical explanations and case analysis in the Partybuilding database. Available at http://djsjk.people.cn/cover.

16 BibCnrs is the portal that providing access to the CNRS (Le Centre national de la recherche scientifique Francais)'s digital document resources. It was developed in 2016 and replaces the previous scientific information portals BiblioPlanets, BiblioSciences, BiblioSHS, BiblioST2I, BiblioVie and TitaneSciences, namely, one of the biggest digital libraries in Europe. 
The first two steps set the foundation for the semantic analysis, but there are far more underlying concepts and metaphors behind the propaganda. Thus, Appendix 1 gives a further keyword correlation analysis to avoid overfitting by focusing on out of sample prediction and selects the best model for the underlying data from a set of candidate models (Van der Vaart, Dudoit and van der Laan, 2006). Correlation analysis based on the feature of the Chinese language can categorize the synonymy or the expressions with a similar meaning, such as the high-frequency words of "Chinese characteristics (Zhongguo te'se 6537)," "characteristics (Te'se 5444)," "socialism (Shehui zhuyi 11608)," "socialism with Chinese characteristics (Zhongguo te'se shehui zhuyi 12380)" can be classified as the Chinese characteristic with the correlated sub-keywords "CCP (Gongchandang 2503)," "party leadership (Dang de lingdao 4255)," "political reform (Zhengzhi gaige 5632)," "problem-oriented (Wenti/Wenti daoxiang 5741)" as the high-frequency words in Appendix 1; keywords like "system/mechanism (Tizhi, Jizhi, total with 15793)," "initialization (Zhiduhua 3717)" and related adjectives can be classified as the institutionalization of the Chinese Xieshang minzhu; The third category is "democracy (Minzhu 21262)," "forms of democracy (Minzhu xingshi 20932)," and "socialism democracy with Chinese characteristics (Shehui zhuyi te'se minzhu 8551)."

Facing simply too many political texts, scholars are rarely able to manually read all the texts in even moderately sized corpora. Hence, in this article, we try to conduct a systematic analysis of the large-scale text collections based on the automated content analysis outlined, within the following three stages:

I. Establishment of the corpus (see the aforementioned description of the foundation of the acquired documents both in Chinese and English for the official discourse).

II. Statistical analysis (1): WordCloud-Pre-treat the Chinese data: decoding, tokenizing, cleaning stop or functional words in the data, analyzing the texts, and visualizing the keywords according to the frequency in the text by Logiciel $\mathrm{R}$ and Python. The cloud that filled with massive words in different sizes represents the frequency or the importance of the keywords ${ }^{17}$; 2). histogram to filter the 20 most used words and their

\footnotetext{
17 We use the rate keywords appear in a text to classify documents into categories or to measure the extent to which documents belong to particular categories. The methodology is not merely dichotomously classified as the positive or negative attitude of the official tone. The words "frequency" and "quantitively analysis" can also identify words that separate categories and measure how often those words occur in texts. For some recent examples that use dictionaries to measure a variety of concepts, those results will be further validated within the standard evaluations in Chinese language, possibly providing an overall comprehension of Chinese Xieshang minzhu in terms of distributing complex attributive concepts and rhetoric issues.
} 
frequency in the data with the third-party support for the histogram in Python-Matplotlib, with the occurrence frequency above 3,000 and also removes the miscellaneous words within the text; 3). Word2vec of correlation network to produce the word embeddings where words or phrases from the vocabulary are mapped to vectors of real numbers, quantify and characterize semantic similarities between linguistic items based on their distributional properties in large samples of language data within continuous skip-gram architecture. Then, adopt the t-SNE to visualize groups of the most similar words in high-dimensional Word2Vec Word Embeddings, which are located in multidimensional space. ${ }^{18}$

III. Semantic results (from the aforementioned analysis, draw the conclusion interspersed with specific numerical analysis).

In the third part, the authors will conduct the semantic analysis based on the following three main categories: I. Xieshang minzhu with Chinese Characteristics (general description; debate of electoral and deliberative democracy in China; and party leadership); II. institutionalization of Xieshang minzhu (participatory devices; Xieshang in the center and local) with various participatory devices; and III. Xieshang minzhu under Chinese democracy discourse. Note that a comparative study with the mirror case and induction of sub-related words within the main categories will also be conducted.

\section{Semantic Results of the Chinese Political Discourse of Xieshang minzhu Xieshang minzhu with Chinese Characteristics}

The authors adopt Chinese Pinyin with Xieshang minzhu for further demonstration instead of English or other linguistical translations, mainly because the Xieshang minzhu per se is quite ambiguous in translation, especially the correspondence and affiliation between Chinese and other languages. ${ }^{19}$ Indigenization of Chinese political scholarship is also increasingly inclined to abandon the rhetoric and linguistic disputes and turn to the analysis of xieshang minzhu with Chinese characteristics. It can be seen from the WordCloud and Histogram above that "Specialism (Te'se 特色)" and

18 We thus, also draw scatter diagrams, as shown in Tables 1 and 2 . The diagrams showed the correlative words of the keywords and also give a clearer visual effect on how the sub-keywords distributed both in the constant $\mathrm{X}$ and $\mathrm{Y}$ coordinates.

19 A number of words and notions have been proposed in the last 15 years to describe the consultative, deliberative, or participatory devices that have developed in China. In English, the authors use terms such as consultative democracy, deliberative democracy, authoritarian deliberation, and authoritarian consultation. In Chinese, the most common word officially used is xieshang minzhu 协商民主, translated differently according to the authors by consultative democracy or deliberative democracy-but another translation of the later English notion of deliberative democracy is shenyi minzhu 审议民主, a term more commonly used in Taiwan and sometimes adopted by Mainland Chinese writers. 
Table 1. Correlation Words and Expressions in Chinese Context

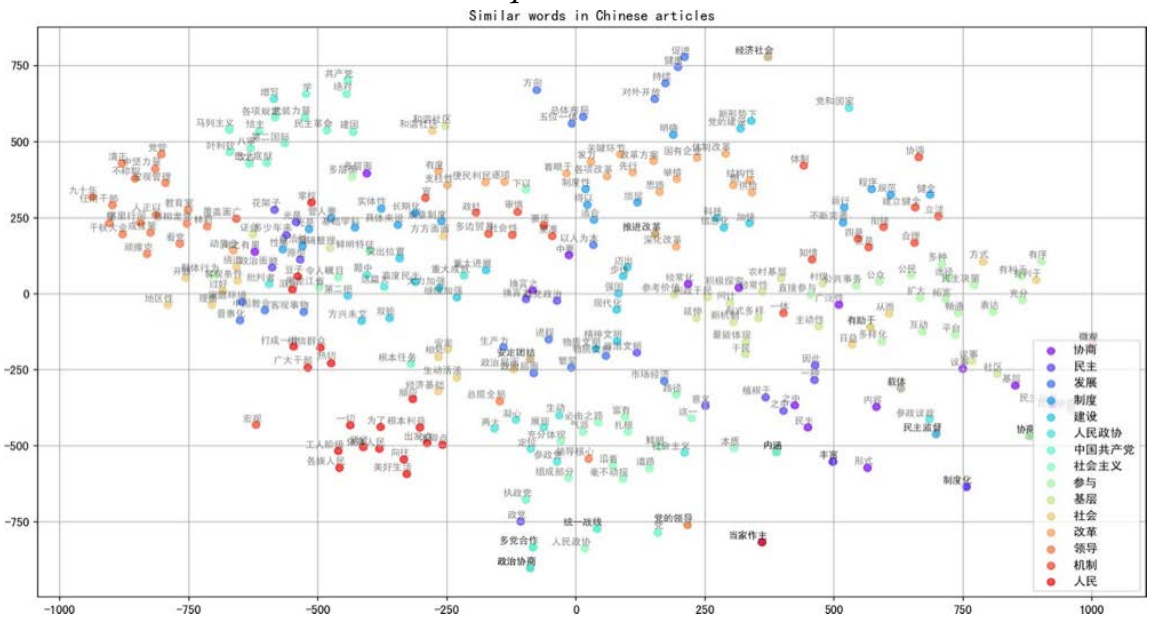

Table 2. Correlation Words and Expressions in English Context

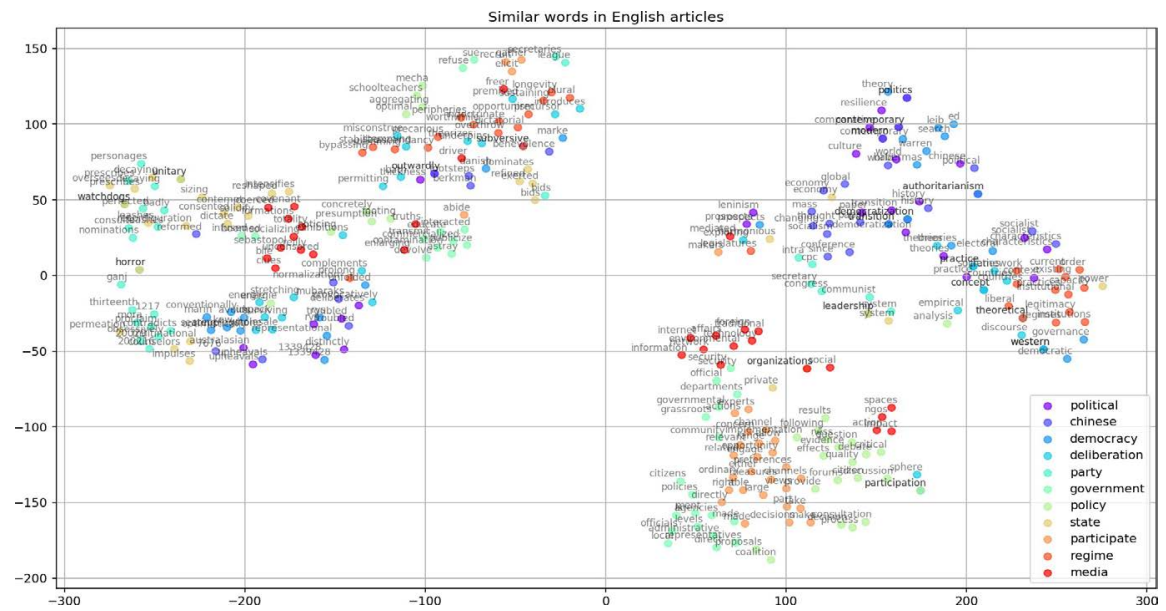

“socialism (Shehui zhuyi 社会主义)" account for the largest proportion, with a frequency of up to 17,500. In addition, according to the correlation map, we divide this part into three sub-subjects with a correlation rate up to $0.6,{ }^{20}$

20 For example, as a keyword of "institutionalization" in Appendix 1, the correlated words that include, according to Appendix 2, "top design" (0.658), "perfect and promotion" (0.572), "management system" (0.568), "full process" $(0.573)$, and so on, but we only select the related words with the correlations more than 0.6 for the text analysis. 
namely: 1) overview of the Xieshang minzhu; 2) controversy of the electoral democracy and Xieshang minzhu in China; and 3) party-dominant.

Both the Western doctrine of deliberative democracy in the Chinese-style deliberative context democracy ${ }^{21}$ and Xieshang minzhu rooted in the Chinese traditional political culture and thought, nevertheless, meet the requirements of netizens' freedom of speech and association, interaction between society and government. Also, deliberative experiments in local China that flourished these years has aroused extensive discussion domestically and even internationally (Li Fan, 2014; e.g., the deliberative institutions in the test case of Wenling city) that indicated the consistency and reconcilable paradox the Xieshang minzhu within China's authoritarianism. But to note, the giant repercussions always with the oppositions, on the one hand, although inspired by the Western deliberative democracy theory, Chinese propaganda and academia lopsided engaged to draw restrictive demarcation with the Western academia in the hope of soliciting the socialist Xieshang minzhu with Chinese characteristics. This trend has been further confirmed by a recent book that discusses 协商民主 Xieshang minzhu (officially translated in foreign languages as consultative democracy) and concludes that it better suits China than multi-party representative democracy. ${ }^{22}$ At the same time, officials and even academia have not yet reached a consensus on the definition of Xieshang minzhu with Chinese characteristics, or the widespread practice of Xieshang or quasi-Xieshang experiments at the local level, which largely lack the necessary theoretical support.

"Election" is a sensitive word that did not appear in the map (see Appendix 1 , the authors extended the word frequency to 50 times, still, no (quasi)"election" was found in the list). In the 1990s, local elections in China came to a halt and slid in a seemingly nonreciprocal manner, while the governments at all levels showed a clear refusal to move to electoral democracy. The direct election of cadres at the very local level in Chengdu, which was regarded as

21 In 2003, "Dangdai xifang zhengzhi lilun de redian wenti (hot issues of contemporary western political theories)" published by Yu Keping introduced the Western deliberative democracy theory for the first time, which aroused the wide attention and enthusiasm in the related studying.

22 Zhou Tianyong, Wang Changjiang and Wang Anling (eds) (2008). "Gongjian shiqidahou zhongguo zhengzhi tizhi gaige yanjiu baogao (Storming the Fortress: A Research Report on China's Political System Reform after the 17th Party Congress)". Xinjiang shengchan jianshe bingtuan chubanshe. (Journal of the Xinjiang Construction corps). pp.32-35; Shangli Li (2003). "Xieshang zhengzhi Dui zhongguo minzhu fazhan de yizhong sikao (Consultative Democracy: A Thinking of the Development of Chinese Political Democracy)". Xueshu yuekan (Academic Monthly). No (4): pp.19-25; Shaoguang Wang (2008). "Jianli yige qiangda de minzhu guojia (Building a Strong Democratic State)". http://www.aisixiang.com/ data/15048.html (accessed 16 December 2016); Guangbin Yang (2014). "Xishi minzhu de kunjing yu zhongguo minzhu de weilai (The Predicament of the "Western Democracy" and the Future of the "Chinese Democracy")". Gongshiwang (21ccom.net), 17July 2014, http:// www.21ccom.net/articles/zgyj/xzmj/article_20140716109514.html (accessed 10 October 2015). 
a prototype, was thus eliminated. The uncertain future toward democracy in China pressurizes the CCP, as well as the Chinese people, to find another form of democracy, rather than electoral (representative) democracy; namely, Xieshang minzhu. This is the congenital flaw of xieshang Minzhu in China, with the legitimized ignorance in official propaganda, also for some Chinese intellectuals, that deliberative and consultative style of democracy is much better than the electoral and conflictual model of liberal democracy (Lin Shangli, 2003).

Nevertheless, the CCP shows no signs of taking a democratic turn, which leaves little room for the discussion of "representative system" and "election" in the Chinese context, especially within the one-party rule. Thus, to the governmental-led sense, Xieshang minzhu is presented with the hope to skip the electoral (representative) democracy in China, and this trend is further confirmed by the top leaders in several speeches ${ }^{23}$ that were more broadly endorsed as a way of reforming the political system in the official document of the Central Party Committee. ${ }^{24}$ In the official framing, the two main forms of socialist democracy in China where elections and voting on the one hand, and full consultations of the people before major decisions are conducted to reach consensus on public issues. ${ }^{25}$ In September 2014, Xi Jinping tackled the sensitive topic of democracy ${ }^{26}$ and stated that: "Democracy is defined not only by people's right to vote in an election but also the right to participate in political affairs on a daily basis. ${ }^{27}$ To say the least, China does not prepare to pursue any kind of democracy, thus mass participation and deliberation are a priority for the short term.

From this lens, the official intention is very obvious, but not absolute. For example, at the local level in China, with village elections, consultative democracy is also required. Rural areas where competitive elections have developed in recent years may contain a genuine consultation of which voting was used in the final stages of public consultation. Thus, elections are the

23 At the celebration of the 65th anniversary of the establishment of the Chinese People's Political Consultative Conference (CPPCC), Xi Jinping emphasized that socialist Xieshang minzhu is the unique form and unique advantage of China's socialist democratic politics and an important embodiment of the mass line of CCP.

24 People's Daily. (2 March 2006).

25 The Opinions of the CPC Central Committee on Strengthening the Work of the CPPCC. Available at: http://cppcc.people.com.cn/GB/34961/60987/.

26 Cary Huang (2014). 'China's Xi Jinping supports “democracy” ... but not in the Western sense', South China Moring Post, (24 September 2014), available at: http://www.scmp.com/news/china/article/1599068/xi-supports- democracy-not-western-sense (accessed 15 May 2017).

27 Xinhua Insight: What does China-Style Democracy Matter to Its People?. Xinhua Net. Available at: http://news.xinhuanet.com/english/2017-03/10/c_136118749.htm (accessed 15 May 2017). 
basis of public consultation that applies only, and more concretely, in the very local context, if any.

Against this background, among all the discourses on Chinese Xieshang minzhu, keywords, such as "party leadership (Dang de lingdao)," "core (Hexin)" and "central place (Zhongxin)," ${ }^{28}$ are high-frequency words and show the paradoxical affiliations between the party and democracy in contemporary China. Xieshang, per se, positively prompts the party leaders to be more responsive and accountable but indicates that how to keep this option or the basic elements in a one-party authoritarian state is still unclear. At one time, the CCP maintained control in an indirect or invisible way. For example, according to the interview with the secretary of the Party Affairs Office in Shuixiu Community, Wuxi indicated that the local community is generally autonomous, local party cadres will not intervene with the internal affairs including various voting meetings. However, if the local issues need mass of funds or under tension, then the director of the neighborhood committee still needs to report to the higher-ups for admissions; namely, the decision-makers are not the participants who voted but the cadres in the office.

\section{Institutionalized and Systematic of Xieshang minzhu}

Official discourses of Xieshang or Xieshng minzhu before the 18th National Congress usually accompanied with the misinterpretation (even in official documents) of "consultative democracy with Chinese characteristic," "socialism consultative democracy," "Chinese-style consultative democracy," and so on. Thus, since Xi's era, that institutionalization has become the focus of official efforts for further promoting Xieshang minzhu, responsibly, institutionalization is also one of the high-frequency words with a total frequency of 2,601. Traditionally, Chinese political culture pays little attention to procedure and institutionalization. Decision-making, therefore, is made by the leaders themselves due to authoritarian reasons with the convictions that procedures are inferior to efficiency. Thus, authorities with strong monopoly expect to achieve the ultimate goal without real deliberation. They even show no interest in deliberating openly (if any, the pressure from the higher-ups).

Further institutionalization of Xieshang or Xieshang minzhu in China is the priority, at best-forcing cadres to follow the deliberative rules in the governance. Such thoughts can be traced back to Mao's mass line, which

28 The Speech at the 65th Anniversary of the Founding of the CPPCC National Committee (2014), Xi Jinping stressed that to develop socialist consultative democracy, we must uphold the leadership of the party. The report of the 19th National Congress of the Communist Party of China (2017) pointed out that consultative democracy is the realization form of the party leadership. Also, the unique form and advantages of China's socialist democracy, etc. 
emphasis on deliberating, listening to, and valuing the voice of the masses politically. Socialist system and culture encourage deliberation, the new type of deliberative governance in Xi's era, that more of the revival of political mobilization adapted for further dealing with the rapid change of economic and civil society, in which cadres and masses jointly solve practical problems, those can also be found in Table 1 as the high-frequency word "problem(oriented)." Thus, Xieshang in China can both solve social conflicts without compromising central authority in a moderate democratization manner, and it can also be regarded as a new form of governance through the integration of executive orders and democratic consultation mechanisms.

Against this background, the CCP intends to design deliberative democratic institutions in a state that was seemingly more open to institutional innovation than many Western democracies, which are set in their ways. He Baogang (2013) summarized various forms of Xieshang system with "democratic talkfest," "citizens' councils," and "urban or village representative assembly." Obviously, the fact that those so-called democratic experiments exist at the local level shows that large-scale institutional design does not seem to be on the agenda. Thus, the deliberation (if any) is carried out under the centralized political structure, and this may cause the inherent tensions; namely, the elites control the deliberative process. As we have seen, the correlative words to institutionalization are mostly present with "top," "discourse power," "wholeprocess" and "dual leadership," for example, that all with the correlation over 0.6. These might be partial summaries centrally but are far from the whole picture of local deliberation. In addition to the decision-making functions of the village committees, the municipal consultative bodies do not have their decision-making mechanisms, which merely functioned for further soliciting public opinions.

\section{Xieshang minzhu Under Chinese-Style Democracy}

Further interpretations of socialism with Chinese characteristics and Xieshang minzhu in Xi's era are all based on the seemingly paradoxical concept of Chinese-style democracy. To date, it is not exactly a political term for just a matter of fact, literature ${ }^{29}$ on the Chinese democratic discourse or

29 See Brantly Womack (1989). Party-State Democracy: A Theoretical Exploration. Issues and Studies. Vol (25). pp.37-57; Baogang He (1996). The Democratization of China. New York: Routledge. pp.40-55; Young Nam Cho (2009). Democracy with Chinese Characteristics? A Critical Review from a Developmental State Perspective. Issues and Studies. Vol(25). pp.71-106; Zhiyue Bo (2010). China's Model of Democracy. International Journal of China Studies. Vol(1). pp.102-124. 
conceptions $^{30}$ is quite large, notwithstanding, some fundamental conclusions that can be drawn from the diverse definitions, that is, Chinese democracy is by no means of the Western-style democracy, namely, multi-party system, open elections, judicial independence, etc., say it, the key factors of modern democracy are not taken into account. The author is more inclined to compare China's democracy as a hybrid type than a merely autocratic one, as criticized by many authors, given that China still maintains a Communist party-state regime and the capability of national mobilization ${ }^{31}$ and limited political participation locally. Ultimately, there can be no political reform that can erode the party dictatorship. Following this logic, it is easy to understand the intention of the CCP for further pioneering Xieshang minzhu, as a form of democracy with Chinese characteristics that can also result in the "fallacy of electoralism." 32

We took the 18th National Congress as a watershed of Xieshang minzhu in contemporary China, within which Xieshang officially embedded in the theoretical system of socialism with Chinese characteristics and became a core component of the democratic thinking in Xi's era. According to Tong's ${ }^{33}$ semantic study of the 19th Report of National Congress, "Xieshang" and "Xieshang minzhu" appeared with a total of 12 times accounted for $9.01 \%$ of the report, "The essence of China's democracy is public affairs should be deliberated by themselves." Xieshang minzhu had been becoming the fifth major democratic form of socialist democracy "as an important way to realize the party leadership" along with the democratic election, democratic management, democratic decision-making, and democratic supervision.

30 See Lu Jie, Shi Tianjian (2015). The Battle of Ideas and Discourses before Democratic Transition: Different Democratic Conceptions in Authoritarian China. International Political Science Review. 36(1): pp.20-41. To be sure, Lu and Shi did provide several alternative democratic discourses in China. For example, from the lens of state craftsmanship based on the Confucius philosophy of guardianship or state-endorsed Leninism, that of following the political doctrines come from the parentage directly or indirectly of the several generation of leadership propaganda like democratic centralism, democracy with Chinese characteristics, 'Three Represents', and 'Harmonious Society'. Also, in the working paper series jointly published by global barometer with a contextualized analysis of the democratic conceptions in East Asian societies, see Lu Jie (2013). Democratic Conceptions in East Asian Societies: A Contextualized Analysis. Taiwan Journal of Democracy. 9(1): pp.117-45. From a more practical perspective, among the diversion democratic conceptions in authoritarian China, a large majority of people are quite satisfied with the practice of democracy rather than pursuing the Western style democracy with free of speech, association, etc., to conclude, the current political scholarships with its discussions are largely within this framework.

31 Tsai Wen-Hsuan (2011). The Concept Construction of Chinese-Style Democracy. Available at SSRN 1904726.

32 Terry Lynn Karl (1995). The Hybrid Regimes of Central America. Journal of Democracy. Vol(6). p.73.

33 Tong Dezhi (2019).The Main Body Empowerment, Procedure and Democratic Effect of Grassroots Consultation in China. Study on Modernization of National Governance. Vol (3). 
Although democracy has always been a sensitive topic in China, it is still the most frequent keyword in Appendix I (21262), while deliberation following with 20,932 is the second place. For understanding China's Xieshang minzhu, it must be placed into the considerations of Chinese-style democracy sphere anyway. At the same time, in the correlative words in Annex II, the democracy-related works like "liberal democracy (0.72)," "replacement (0.66)," "argument (0.65)," "democratic election (0.65)" strongly shows that Chinese-style democracy is distinct from Western-style democracy-liberal democracy. Neither the authorities nor academia conceals the formulation with the "socialism with Chinese characteristics" as a hot topic in domestic academic research.

The interpretation of China's Xieshang minzhu in this dimension cannot be isolated against this backdrop. That is, CCP reinforce the path of Chinese democracy by reaffirming Xieshang or Xieshang minzhu in Chinese politics. ${ }^{34}$ This can also be found in appendix 1 with the high-frequency keyword like “people (Renmin 人民 9595)," which as the core concept in Chinese democracy with the doctrine of the "people are the masters of the state," despite criticized by its utopian idea and not yet wildly recognized as a kind of democratic theory. Nevertheless, Chinese democracy does provide the theoretical support for the political consultation and deliberation, and also clearly state the relationship between the deliberative democracy and electoral democracy in China from this lens. Interpretations like "China model (Zhongguo moshi 中 国模式)," “China Road (Zhongguo daolu 中国道路)”35 that are presented in a seemingly more firmly permeable manner in the political discourse, strongly engaging the deliberation within. Simultaneously, "political consultation (Zhengzhi xieshang政治协商)," “intra-party deliberation (Zhengdang xieshang 政党协商)," “political consultative conference (Zhengxie 政协)” as the highfrequency (sub) keywords also indicate China's basic political system, namely the political consultation system with the CPPCC as the main body. As Yan Jirong (2017) put it, "China's political consultation system will not regard

34 Opinions of CCP Central Committee on Strengthening the Work of the People's Political Consultative Conference stated that: "People exercise their rights through elections and voting, and also fully deliberations before major decisions, are two important forms of socialist democracy in China," which means that political consultation and deliberation are seen as an important form of democracy alongside with elections (voting) democracy. Yan Jirong, professor in Beijing University, also put that, in the modern China, CCP focuses on the democratization from "referendum" and elections to the free and equal debate and consultation.

35 On July 1, 2016, Xi Jinping clearly stated in his important speech at the 95th anniversary of the founding of the Communist Party of China that, "the whole party should ultimately adhere to the 'Four Confidences' of 'road confidence, theoretical confidence, institutional confidence, and cultural confidence." for the first time, juxtaposition the party-leadership as the core and the 'Four Confidences' as a whole. 
the free elections, open party bans, military nationalization and separation of powers as the prerequisite and merely approach to advance China's democratization. Democracy is a thing that should be able to quickly reflect the will of people, namely, management performance is therefore, priority than democratic elections." 36

Sometimes, it may unpersuasive and ironic about the official discourse "democracy with Chinese characteristics" or the other synonyms, within which the CCP disguised itself with an authoritarian rule through pseudodemocratic political reform. But interestingly, from a duplex perspective, Chinese authorities successfully doctrine its people with such preset democratic model to distinguish it with the Western democracy thus further highlight its priorities in a nonelectoral and less-noxious manner; also to note, the democratic conceptions among the Chinese people do provide the regime support, although this article does not engage the discussion on how Chinese people shape their ideas of democracy, or concretely, deliberative democracy, it turned to be, according to the arguments of He Baogang (2014) on Chinese conception of deliberation, deliberation is more like the moral codes that solving conflicts in a peaceable way from a historical and cultural perspective. This is also well explained by the interaction between the state and society in a nonofficial perspective through the deliberative approach.

\section{Conclusion}

The CCP faces great pressure when confronting the wave of democratization worldwide. At the same time, the fission and degradation of the late-developing state (socialist regime) after adopting the liberal democracy also strongly alert China to the need to find its path. Scholarship on China studies focuses on the democratic transformation and authoritarian resilience, which rarely size up China's political reforms in a non-Western perspective. The criticismsnamely, China's so-called democratic reforms are far from satisfying democratic demand, or, the extremely inconsistency between China's political reform and economic development- to some extent, may make sense. It does not necessarily lead to the legitimacy of China's "authoritarianism" through some short-term economic achievements and superficial political reforms. Thus, from this lens, using the term democracy to describe such ventures seems to let the Chinese government off too easily.

Anyway, rather than immerse in the conceptual disputes of deliberative democracy in Chinese context, we thus adopted the official description of

36 Yan Jirong (2017). Democracy: Is it elected or Deliberated? - On the value and enlightenment of deliberative democracy. Conference paper. 
consultative democracy for further avoiding the semantic and rhetorical ambiguities. At the same time, contributions of this article are more likely to reinterpret the official discourse following the CCP's original intention rather than academic misreading by adopting semantic analysis within the Chinese language. Technical means like Word2 VEC, python further contribute to a more precise text analysis base on the preset corpus. In short, Xieshang minzhu is different from the Western deliberative democracy, nevertheless, in line with the current China's governmental innovation by calling for limited participation and consultation within the one-party rule. Second, amazing yet true, it was the authoritarian rules who feel the need to establish more thoroughgoing institutional design in the political reforms, which included the establishment of central and local consultative/deliberative institutions and the wildly preexisted democratic experimentations in the local. Finally, against the background of the Chinese style democracy, Xieshang minzhu itself, as well as other political discourses, therefore, would ultimately be an integral part within the Chinese socialism design and further serve for the CCP's legitimacy. Whether Xieshang minzhu can eventually become a driving force for China's truly democracy or an expedient choice for evading elections as a transformational option, it always provides a fresh non-Western-centered perspective for with both scholars and practitioners to further discuss the political envision of China.

\section{References}

Atkinson, K. M., Bench-Capon, T. J., Cartwright, D., and Wyner, A. Z. (2011). Semantic Models for Policy Deliberation. In Proceedings of the 13th International Conference on Artificial Intelligence and Law. pp.81-90.

Austen-Smith, David, and Timothy J. Feddersen (2008). In Response to Jurg Steiner's 'Concept Stretching: The Case of Deliberation'. European Political Science. 7(2): pp.191-193.

Baogang He (1996). The Democratization of China. New York: Routledge. pp.40-55.

Burden, Barry and Joseph Sanberg (2003). Budget Rhetoric in Presidential Campaigns from 1952 to 2000. Political Behavior. 25(2): pp.97-118.

Doerr Nicole (2012). Translating Democracy: How Activists in the European Social Forum Practice Multilingual Deliberation. European Political Science Review. 4(3): pp.361-384.

Dryzek, John S. (1990). Discursive Democracy: Politics, Policy, and Political Science. New York: Cambridge University Press.

Fiket, I., Olsen, E.D.H. and Trenz, H.-J. (2011). Deliberation under Conditions of Language Pluralism. Insight from the Europol's Deliberative Polling Experiment. Arena Working Paper. $\operatorname{Vol}(9)$.

Guangbin Yang (2014). "Xishi minzhu de kunjing yu zhongguo minzhu de weilai (The Predicament of the "Western Democracy" and the Future of the "Chinese Democracy")". 


\section{Rongxin Li, Xiaofang Zhou \\ A Semantic Analysis of the Notion of Consultative Democracy}

Gongshiwang (21ccom.net), 17 July 2014, http://www.21ccom.net/articles/zgyj/xzmj/article_20140716109514.html (accessed 10 October 2015).

He Baogang (2016). Western Theories of Deliberative Democracy and the Chinese Practice of Complex Deliberative Governance. The Search for Deliberative Democracy in China. Palgrave Macmillan. pp.133-148.

Hofann Hasso (1964). Legitimität gegen Legalität: der Weg der politischen Philosophie Carl Schmitts. Neuwied: Luchterhand.

Jrrgen Habermas (1994). Citizenship and National Identity. In Bart Van Steenberg ed., The Condition of Citizenship. London: Sage Publications. pp.20-35.

Kellstedt, Paul (2000). Media Framing and the Dynamics of Racial Policy Preferences. American Journal of Political Science. 44(2): pp.245-260.

Koselleck Reinhart (ed.) (1979). Historische Semantik und Begriffsgeschichte. Stuttgart: Klett-Cotta.

Laver, Michael and John Garry (2000). Estimating Policy Positions from Political Texts. American Journal of Political Science. 44(3): pp.619-634.

Leib, Ethan J (2005). The Chinese Communist Party and Deliberative Democracy. Journal of Public Deliberation. 1(01): p.1.

Lin Shangli (2003). Deliberative Politics: A Reflection on the Democratic Development of China. Academic Monthly (Shanghai).Vol(4): pp.19-25.

Ma Ben (2014). "Xieshangminzhu yu xuanjuminzhu: yuanyuan, guanxi yu weilaifazhan. (Consultative Democracy and Electoral Democracy: Origin, Relationship and Future Development)". Wenzheshi. Literature, history and philosophy. Vol(03): pp.21-26.

Maaten, L. V. D., and Hinton, G. (2008). Visualizing Data Using t-SNE. Journal of Machine Learning Research. Journal of Machine Learning Researchpp. pp.2579-2605.

Mikolov T., Sutskever I., Chen K., Corrado G. S. and Dean J. (2013b). Distributed Representations of Words and Phrases and Their Compositionality. In Advances in Neural Information Processing Systems. pp.3111-3119.

Mikolov T., Sutskever I., Chen K., Corrado G. S. and Dean J. (2013a). Efficient Estimation of Word Representations in Vector Space. In: ICLR: Proceeding of the International Conference on Learning Representations Workshop Track. pp.1301-3781.

Mikolov T., Yih W.-T. and Zweig G. (2013c). Linguistic Regularities in Continuous Space Word Representations. In Hlt-naacl. Vol(13): pp.746-751.

Mulieri, Alessandro (2016). Hasso Hofmann and the Polysemy of Representation. Redescriptions: Political Thought. Conceptual History and Feminist Theory. 19(2): pp.127-145.

Pitken, Hanna F. (1967). The Concept of Representation. Berkeley: University of California Press.

Shangli Li (2003). "Xieshang zhengzhi Dui zhongguo minzhu fazhan de yizhong sikao (Consultative Democracy: A Thinking of the Development of Chinese Political Democracy)". Xueshu yuekan (Academic Monthly). No(4): pp.19-25;

Shaoguang Wang (2008). "Jianli yige qiangda de minzhu guojia (Building a Strong Democratic State)". Available at http://www.aisixiang.com/data/15048.html (accessed 16 December 2016). 


\section{Journal of Nationalism, Memory \& Language Politics 14(1)}

Steiner, Jürg (2008). Concept Stretching: The Case of Deliberation. European Political Science. 7(2): pp.186-190.

Sun Dehai and Fang Shinan (2015). "Zhongguo tese xieshangminzhu lilun yu huayujiangou de fenxi. (Theoretical Analysis of Deliberative Democracy and Discourse Construction with Chinese Characteristics)". Tansuo. Exploration. Vol (06): pp.56- 62.

Terry Lynn Karl (1995). The Hybrid Regimes of Central America. Journal of Democracy. $\operatorname{Vol}(6)$. p.73.

Tsai Wen-Hsuan (2011). The Concept Construction of Chinese-Style Democracy. Available at SSRN 1904726.

Van der Laan, Mark, Eric Polley and Alan Hubbard (2007). Super Learner. Statistical Applications in Genetics and Molecular Biology. 6(1).

Womack (1989). Party-State Democracy: A Theoretical Exploration. Issues and Studies. $\operatorname{Vol}(25)$. pp.37-57;

Young Nam Cho (2009). Democracy with Chinese Characteristics? A Critical Review from a Developmental State Perspective. Issues and Studies. Vol(25). pp.71-106;

Young, Lori and Stuart Soroka (2011). A_ective News: The Automated Coding of Sentiment in Political Texts. Political Communication. Forthcoming.

Zhiyue Bo (2010). China's Model of Democracy. International Journal of China Studies, $\operatorname{vol}(1)$. pp.102-124.

Zhou Tianyong, Wang Changjiang and Wang Anling (eds) (2008). "Gongjian shiqidahou zhongguo zhengzhi tizhi gaige yanjiu baogao (Storming the Fortress: A Research Report on China's Political System Reform after the 17th Party Congress)”. Xinjiang shengchan jianshe bingtuan chubanshe. (Journal of the Xinjiang Construction corps). pp.32-35; 


\section{Appendix 1 Word Cloud Map and Numerical Quotieties}

Word Cloud Map in Chinese

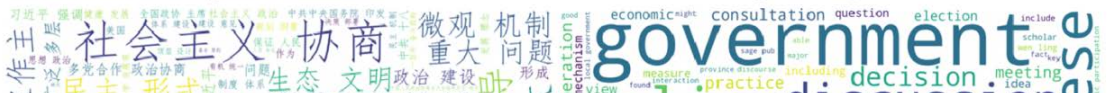

㳑国家 治理

叫等人民建立基昙

人民“群众

特色社会主义

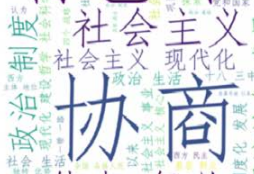

伟大复兴
Word Cloud Map in English

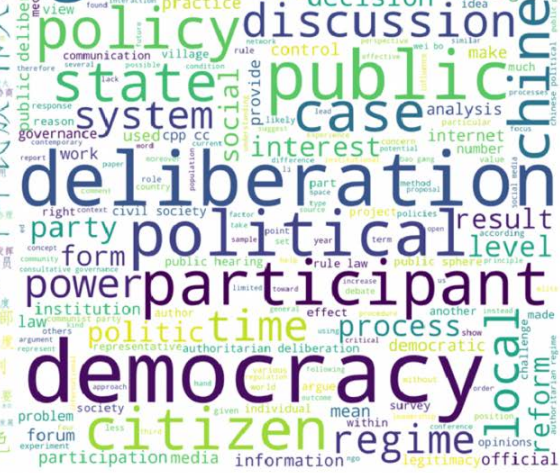

Graph of Chinese Word Frequency with Numerical Quotieties

Note: The translation of each index of the abscissa is: democracy, Xieshang, development, socialist, institution, construction, people, state, society, politics, problem, reform, characteristic, Xi Jinping, system, leadership, mass, local, systematic, governance. 
Journal of Nationalism, Memory \& Language Politics 14(1)

\section{Appendix 2 Comparison Table of Chinese and English Word Frequency}

Appendix 1 Comparison Table of Chinese and English Word Frequency

\begin{tabular}{|c|c|c|c|c|c|c|c|}
\hline Chinese Key Words & No & $\begin{array}{c}\text { English key } \\
\text { words }\end{array}$ & No & Chinese Key Words & No & English key words & No \\
\hline 民主 Minzhu & 21262 & Political & 4526 & 群众 Qunzhong & 4135 & System \\
\hline $\begin{array}{c}\text { 协商 Xieshang } \\
\text { 发展 Fazhan }\end{array}$ & 20932 & Public & 4344 & 基层 Jiceng & 3795 & Regime & 1210 \\
\hline $\begin{array}{c}\text { 社会主义 } \\
\text { Shehuizhuyi }\end{array}$ & 11608 & Democracy & 3397 & 体系 Tixi & 治理 Zhili & 3647 & 1200 \\
\hline
\end{tabular}

\begin{tabular}{|c|c|c|c|c|c|c|c|}
\hline 制度 Zhidu & 11075 & Deliberation & 3345 & 中国共产党 Zhongguo gongchandang & 3461 & Media & 1147 \\
\hline 建设 Jianshe & 10224 & Government & 2939 & 形式 Xingshi & 3083 & Information & 1138 \\
\hline 人民 Renmin & 9595 & Party & 2916 & 人民政协 Renmin zhengxie & 3077 & Internet & 1137 \\
\hline 国家 Guojia & 8932 & Social & 2316 & 进行 Jinxing & 2940 & Level & 1133 \\
\hline 社会 Shehui & 8754 & Policy & 2162 & 作用 Zuoyong & 2906 & Power & 1114 \\
\hline 政治 Zhengzhi & 8551 & State & 1918 & 意见 Yijian & 2844 & Law & 1071 \\
\hline 问题 Wenti & 5741 & Local & 1905 & 重大 Zhongda & 2831 & Discussion & 1002 \\
\hline 改革 Gaizhe & 5632 & Democratic & 1500 & 保障 Baozhang & 2767 & Consultative & 985 \\
\hline 特色 Tese & 5444 & Authoritarian & 1478 & 全国 Quanguo & 2735 & Process & 952 \\
\hline 习近平 $\mathrm{Xi}$ Jinping & 5082 & Governance & 1452 & 政府 Zhengfu & 2712 & Citizens & 948 \\
\hline 机制 Jizhi & 4718 & Society & 1256 & 基本 Jiben & 2690 & Economic & 867 \\
\hline 领导 Lingdao & 4255 & Participation & 1242 & 思想 Sixiang & 2671 & Consultation & 837 \\
\hline 要求 Yaoqiu & 2633 & Rule & 801 & 理论 Lilun & 2250 & Number & 560 \\
\hline $\begin{array}{c}\text { 委员会 } \\
\text { Weiyuanhui }\end{array}$ & 2602 & Reform & 779 & 实施 Shishi & 2250 & Elections & 538 \\
\hline 历史 Lishi & 2599 & Institutions & 778 & 作为 Zuowei & 2488 & Analysis & 661 \\
\hline 时代 Shidai & 2593 & Decision & 768 & 建立 Jianli & 2464 & Civil & 637 \\
\hline 委员 Weiyuan & 2574 & Case & 706 & 参与 Canyu & 2454 & Discourse & 635 \\
\hline 不断 Buduan & 2518 & Legitimacy & 699 & 决定 Jueding & 2445 & Time & 623 \\
\hline 中央 Zhongyang & 2503 & Theory & 670 & 提高 Tigao & 2387 & International & 616 \\
\hline
\end{tabular}


Rongxin Li, Xiaofang Zhou A Semantic Analysis of the Notion of Consultative Democracy Appendix 2 Comparison Table of Chinese and English Word Correlation

\begin{tabular}{|c|c|c|c|c|c|c|c|}
\hline \multicolumn{2}{|c|}{ Appendix 2 Comparison Table of Chinese and English Word Correlation } \\
\hline Word & Similarity & Word & Similarity & Word & Similarity & Word & Similarity \\
\hline \multicolumn{2}{|c|}{ 协商 } & \multicolumn{2}{|c|}{ Politics } & 事务 & 0.641609251499176 & Discussion & 0.8995268940925600 \\
\hline 民主协商 & 0.8089141845703130 & Troubled & 0.9180566668510440 & 直接参与 & 0.6348832845687870 & Citizen & 0.8835697770118710 \\
\hline 含义 & 0.7068020701408390 & Democratization & 0.8979698419570920 & 集思广益 & 0.6341352462768560 & Decision & 0.8792120814323430 \\
\hline 参在 & 0.7020663022995000 & Modern & 0.8977453708648680 & 流动 & 0.633746862411499 & Concretely & 0.8678337931633000 \\
\hline 问计 & 0.698516309261322 & Authoritarianism & 0.8972874879837040 & & Results & 0.8595625162124630 \\
\hline 怎谈 & 0.6975975036621090 & Chinese & 0.8943853378295900 & 农村基层 & 0.7411943078041080 & Debate & 0.8589524626731870 \\
\hline 政治协商 & 0.6728807687759400 & Contemporary & 0.8924946188926700 & 直属单位 & 0.6840132474899290 & Quality & 0.8583760857582090 \\
\hline
\end{tabular}

\begin{tabular}{|c|c|c|c|c|c|c|c|}
\hline 还权 & 0.6650855541229250 & Politics & 0.8865674138069150 & 村级 & 0.6666668653488160 & & State \\
\hline & 民主 & Transition & 0.881643533706665 & 社区 & 0.6605402827262880 & Organizations & 0.8911443948745730 \\
\hline 自由民主 & 0.7239042520523070 & Resilience & 0.8791048526763920 & 高校 & 0.6557683944702150 & Dominates & 0.8696194887161260 \\
\hline 民主协商 & 0.699310839176178 & \multicolumn{2}{|c|}{ Chinese } & \multicolumn{2}{|r|}{ 社会 } & Intensifies & 0.8693302869796750 \\
\hline 含义 & 0.6693841218948360 & Political & 0.8943853378295900 & 次要矛盾 & 0.7036345 .0050354 & Reshaped & 0.8481143712997440 \\
\hline 代替 & 0.6643035411834720 & History & 0.8781710863113400 & 莱体经济 & 0.6610291004180910 & Refined & 0.8456662893295290 \\
\hline 政党政治 & 0.6631795167922970 & Modern & 0.8713786602020260 & 政局 & 0.6012859344482420 & Reconfiguration & 0.8441237211227420 \\
\hline 论争 & 0.6594923138618470 & World & 0.8670737147331240 & 村级 & 0.5989202857017520 & Exerted & 0.8388341665267940 \\
\hline 民主选举 & 0.6566796898841860 & Contemporary & 0.8652957081794740 & 民族团结 & 0.5977252721786500 & Watchdogs & 0.8375169038772580 \\
\hline & 发展 & Reformed & 0.8605055212974550 & 职业性 & 0.59515380859375 & \multicolumn{2}{|c|}{ Participation } \\
\hline 布局 & 0.6825392246246340 & Transition & 0.8569412231445310 & & 改革 & Relevant & 0.9934195280075070 \\
\hline 上层建的 & 0.6645612120628360 & Democratization & 0.8557011485099790 & 各项改革 & b.6006082892417910 & Decisions & 0.9887282848358150 \\
\hline 转型 & 0.6419936418533330 & \multicolumn{2}{|c|}{ Democracy } & 体制改革 & 0.5904462337493900 & Recruit & 0.9877291917800900 \\
\hline & 制度 & Authoritarianism & 0.8976691961288450 & 改革方案 & 0.5679440498352050 & Directly & 0.9865315556526180 \\
\hline 顶层 & 0.6586638689041140 & Democratic & 0.8858753442764280 & 先行 & 0.5634280443191530 & Makers & 0.9865061640739440 \\
\hline 制度性 & 0.593192994594574 & Theories & 0.881677508354187 & 便民利民 & 0.5542479753494260 & \multicolumn{2}{|c|}{ Regime } \\
\hline 话语 & 0.5914607048034670 & Governance & 0.876510739326477 & 发展性 & 0.552341878414154 & Regimes & 0.9800976514816280 \\
\hline 出谋献策 & 0.5803865194320680 & Search & 0.8716925978660580 & \multicolumn{2}{|r|}{ 领导 } & Legitimacy & 0.9723701477050780 \\
\hline 不断完善 & 0.5727893114089970 & Representational & 0.8714632391929630 & 党政领导 & 0.7945212125778200 & Peripheries & 0.9629878997802730 \\
\hline 全过程 & 0.570304274559021 & Practice & 0.8691146373748780 & 大力支持 & 0.7663915753364560 & Stemming & 0.9494221806526180 \\
\hline 管理制度 & 0.568 .493127822876 & Theory & 0.8681017160415650 & 领导核心 & 0.7478739023208620 & Stabilize & 0.9482384324073790 \\
\hline & 建设 & \multicolumn{2}{|c|}{ Deliberation } & 不称职 & 0.7188001871109010 & Precarious & 0.9469283223152160 \\
\hline 事业心 & 0.6145085096359250 & Permitting & 0.9235591888427730 & 管理权限 & 0.7130711674690250 & Prolong & 0.9407248497009280 \\
\hline 创建活动 & 0.5990373492240910 & Precursor & 0.900804877281189 & & 机制 & Indoctrinate & 0.9394563436508180 \\
\hline 革命化 & 0.5978469252586370 & Participation & 0.9000261425971990 & 障碍 & 0.6824522018432620 & Capacity & 0.9361817836761480 \\
\hline 物质文明 & 0.5966802835464480 & Empirical & 0.8940379619598390 & 财政管理 & 0.6783745288848880 & Liberal & 0.9330846071243290 \\
\hline & 民政协 & Sphere & 0.8865604400634770 & 弊端 & 0.668919026851654 & & Media \\
\hline 试金石 & 0.7864826917648320 & Concept & 0.8797206878662110 & 双重领导 & 0.6387591361999510 & Internet & 0.9272285103797910 \\
\hline 统一战线 & 0.7859411835670470 & Theoretical & 0.8736478090286260 & 网络系统 & 0.6317857503890990 & Social & 0.8961520195007320 \\
\hline
\end{tabular}


Journal of Nationalism, Memory \& Language Politics 14(1)

\begin{tabular}{|c|c|c|c|c|c|c|c|}
\hline 政协 & 0.7128431797027590 & Discourse & 0.87296462059021 & 保障机制 & 0.6247758865356450 & Information & 0.8778412342071530 \\
\hline 中心环节 & 0.7117583751678470 & Surviving & 0.8670330047607420 & 指标体系 & 0.6204280257225040 & Network & 0.8620261549949650 \\
\hline 多党合作 & 0.7084617018699650 & \multicolumn{2}{|c|}{ Party } & \multicolumn{2}{|r|}{ 人民 } & Environmental & 0.8553221225738530 \\
\hline 政治协商 & 0.6972354054450990 & Leadership & 0.9166043996810910 & 各族人民 & 0.7423746585845950 & Affairs & 0.8402619361877440 \\
\hline 参政党 & 0.6908050775527950 & Communist & 0.8983123302459720 & 依靠职工 & 0.6845540404319760 & Security & 0.8381603956222530 \\
\hline 实打实 & 0.6881098747253420 & Consults & 0.8872755765914920 & 劳动者 & 0.678101658821106 & Ngos & 0.8368843793869020 \\
\hline \multicolumn{2}{|c|}{ 中国共产党 } & Intra & 0.8717651963233950 & 密切联系 & 0.672268807888031 & & \\
\hline 共产党 & 0.8240038156509400 & $\mathrm{Cpc}$ & 0.8638969659805300 & 党和人民 & 0.6714665293693540 & & \\
\hline 核心作用 & 0.7259838581085210 & Personages & 0.863227367401123 & 劳动 & 0.6709963083267210 & & \\
\hline $\begin{array}{c}\text { 抗日民族统一 } \\
\text { 战线 }\end{array}$ & 0.7077821493148800 & Prescribes & 0.8571782112121580 & 农民 & D.6610420942306520 & & \\
\hline 绝对 & 0.6976900100708010 & Decaying & 0.8556762933731080 & 保障人权 & 0.6514425277709960 & & \\
\hline 集中统一 & 0.6934772729873660 & League & 0.8511752486228940 & & & & \\
\hline 干部带头 & 0.6879535913467410 & \multicolumn{2}{|c|}{ Government } & & & & \\
\hline \multicolumn{2}{|c|}{ 社会主义 } & Agencies & 0.9279177188873290 & & & & \\
\hline 物质文明 & 0.7218929529190060 & Commercialized & 0.9238135814666750 & & & & \\
\hline 共同理想 & 0.7146956920623780 & Officials & 0.9151060581207280 & & & & \\
\hline 特色 & 0.7031674385070800 & Publicize & 0.9081112146377560 & & & & \\
\hline 理论体系 & 0.6979420781135560 & Administrative & 0.9021355509758000 & & & & \\
\hline 必由之路 & 0.6930296421051030 & Levels & 0.8990692496299740 & & & & \\
\hline 群众性 & 0.6925210952758790 & Policies & 0.8978558778762820 & & & & \\
\hline \multicolumn{2}{|r|}{ 参与 } & \multicolumn{2}{|c|}{ P'olicy } & & & & \\
\hline 参与度 & 0.7344537973403930 & Consultation & 0.9275849461555480 & & & & \\
\hline 获取 & 0.6573069095611570 & Analysis & 0.9166003465652470 & & & & \\
\hline 积极参与 & 0.6523089408874510 & Process & 0.9009864330291750 & & & & \\
\hline
\end{tabular}

